\title{
DOMICILE PREFERENCES IN EMPLOYMENT: THE CASE OF ALASKA HIRE
}

In 1972 the state of Alaska enacted legislation, commonly referred to as "Alaska Hire," requiring private employers to give Alaskan citizens a first-hired, last-fired preference in jobs arising from state oil and gas leases. ${ }^{1}$ The stated purposes of the hiring preference ${ }^{2}$ were to upgrade Alaska's human resources in conjunction with natural resource management ${ }^{3}$ and to reduce unemployment. ${ }^{4}$ The hiring preference

\footnotetext{
THE FOLLOWING CITATIONS WILL BE USED IN THIS NOTE: RIE];

B. CURRIE, SELECTEd EsSAYS ON THE CONFLICT OF LAWS (1963) [hereinafter cited as CUR-

L. Tribe, American Constitutional Law (1978) [hereinafter cited as Tribe].

1. ALASKA STAT. $\$ 38.40$ (1977). These jobs include work in the extraction and distribution of oil and gas as well as related pipeline construction. Section 38.40.050(a) provided:

Applicability of chapter. (a) The provisions of this chapter apply to all employment which is a result of oil and gas leases, easements, leases or right-of-way permits for oil or gas pipeline purposes, unitization agreements or any renegotiation of any of the preceding to which the state is a party after July 7, 1972; however, the activity which generates the employment must take place inside the state and it must take place either on the property under the control of the person subject to this chapter or be directly related to activity taking place on the property under his control and the activity must be performed directly for the person subject to this chapter or his contractor or a subcontractor of his contractor or a supplier of his contractor or subcontractor.
}

["Person subject to this chapter" refers to an employer-lessee. "Property under his control" refers to property acquired by lease or right-of-way permit.]

2. ALASKA StaT. $\$ 38.40 .030$ (a) (1977), which established the hiring preference, provided:

Resident employment. (a) In order to create, protect and preserve the right of Alaska residents to employment, the commissioner of natural resources shall incorporate into all oil and gas leases, easements or right-of-way permits for oil or gas pipeline purposes, unitization agreements, or any renegotiation of any of the preceding to which the state is a party, provisions requiring the lessee to comply with applicable laws and regulations with regard to the employment of Alaska residents, a provision requiring the employment of Alaska residents, a provision prohibiting discrimination against Alaska residents, and, when in the determination of the commissioner of natural resources it is practicable, a provision requiring compliance with the Alaska Plan, all in accordance with the provisions of this chapter.

3. State Policy. It is the policy of the state in the development of its natural resources to seek and accomplish the development of its human resources by providing maximum employment opportunities for its residents in conjunction with natural resource management.

ALASKa StAT. \& 38.40 .010 (1977).

4. Legislative findings. The legislature finds that Alaska has a uniquely high unemployment record among the states due both to cultural and geographical migration barriers which record has existed for many years and which experts have attested will persist without drastic governmental intervention. The legislature further finds that employment opportunities which from time to time occur in the areas of the state suffering from the largest chronic unemployment problem are nonrecurring and usually relate to the 
went to those having a physical presence in Alaska ${ }^{5}$ and presenting several indicia of intent to remain in the state. ${ }^{6}$ The preference thus was for persons domiciled in the state or bona fide residents. ${ }^{7}$ In 1977 the Alaska Supreme Court struck down as unconstitutional the preference's durational residency or "waiting period" component. ${ }^{8}$

This Note focuses on the constitutional validity of Alaska's nondurational domicile employment preference. The analysis covers the article IV privileges and immunities clause and the interstate commerce clause of the United States Constitution and the dimensions of state leasing power. The Note looks favorably upon Hicklin $v$. Orbeck, ${ }^{9}$ in which a unanimous United States Supreme Court invalidated the nondurational aspects of Alaska Hire ${ }^{10}$ on privileges and immunities clause grounds. ${ }^{11}$ Finally, it examines some of the adverse consequences of using other possible domicile employment preferences.

exploitation of the state's natural resources and that the state has an obligation to assure that the benefits of this employment enure to the residents of the state.

ALASKa STAT. § 38.40 .020 (1977).

5. Before the striking of the durational aspects of the resident hiring preference, see note 9 infra, Alaska STAT. $§ 38.40 .090(1)(A)$ (1977) provided:

Definitions. In this chapter (I) "resident" means a person who (A) except for brief intervals, military service, attendance at an educational or training institution, or for absences for good cause, is physically present in the state for a period of one year immediately before the time his status is determined .... .

6. Both the statutory language and its judicial interpretation focused on intent. The statute provided that " $(1)$ 'resident' means a person who . . . (E) shows by all attending circumstances that his intent is to make Alaska his permanent residence ...." Alaska STAT. \& $38.40 .090(1)(E)$ (1977). With the exception of the one year residency requirement found in $\S$ 38.40.090(1)(A), see note 9 infra, the Alaska Supreme Court approved the use of the objective indicia listed in $\$ 38.40 .090(1)$ to determine whether an applicant had the subjective intent required by $\S 38.40 .090(1)$ (E). Hicklin v. Orbeck, 565 P.2d 159, 171 (Alas. 1977), rev'd, $98 \mathrm{~S}$. Ct. 2482 (1978). Hence, among the matters to be considered were whether the applicant was one who "(B) maintains a place of residence within the State; (C) has established residency for voting purposes within the State; [and] (D) has not, within the period of required residency, claimed residency in another state ...." $\$ 38.40 .090(1)(B)-(D)$.

7. See Hicklin, 565 P.2d at 171.

8. See note 9 infra.

9. $98 \mathrm{~S}$. Ct. 2482 (1978). The eight Hicklin plaintiffs had applied for jobs on the Alaska pipeline. The defendants, the Alaska Commissioners of Labor and Natural Resources, refused to grant the plaintiffs the necessary permission to obtain such employment on the grounds that the plaintiffs met neither the one year nor the bona fide residency requirements of Alaska Hire. The plaintiffs brought suit in state superior court contesting both residency tests. The trial court upheld the law in its entirety. See Hicklin v. Orbeck, 565 P.2d 159, 162 (Alas. 1977), rev'd, 98 S. Ct. 2482 (1978). On appeal the Alaska Supreme Court unanimously found the durational requirement violative of the fundamental right to interstate travel. 565 P.2d at 162-63 (citing inter alia Shapiro v. Thompson, 394 U.S. 618 (1969) (one year residency requirement for welfare benefits invalidated)). The court then divided three to two in upholding the domicile test. The plaintiffs appealed only this affirmance of the nondurational residency requirement to the United States Supreme Court. 98 S. Ct. at $2486 \&$ n.6.

10. See note 6 supra.

11. 98 S. Ct. at 2488,2492 n.19. 


\section{The Privileges and Immunities Clause}

The privileges and immunitites clause of article IV, section 2 of the United States Constitution provides that "[ $t]$ he Citizens of each State shall be entitled to all Privileges and Immunities of Citizens in the several States." 12 The provision is sometimes called the "interstate privileges and immunities clause," 13 since it serves to insure "a citizen of State $A$ who ventures into State $B$ the same privileges which the citizens of State $B$ enjoy."14, It should be distinguished from the equal protection clause, which prohibits state discrimination against "person[s] within its jurisdiction," 15 and the fourteenth amendment privileges and immunities clause, ${ }^{16}$ which purports to protect the privileges of national citizenship from state infringement. ${ }^{17}$

The intended political function of the article IV clause was to "help fuse into one Nation a collection of independent, sovereign States." 18 The early case history of the provision reflects a debate over whether promoting this function required each state to guarantee to noncitizens only those rights which are "fundamental [and belong] to the citizens of all free governments" 19 or required them also to guarantee all rights granted to each state's own citizens. ${ }^{20}$ For a long period

12. U.S. Const. art. IV, $\S 2$.

13. See W. Lockhart, Y. Kamisar \& J. Choper, Constitutional Law: Cases-ComMENTS-QUESTIONS 391 (4th ed. 1975).

14. Toomer v. Witsell, 334 U.S. 385, 395 (1948). The Hicklin Court noted that "the terms 'citizen' and 'resident' are 'essentially interchangeable"' in this context. $98 \mathrm{~S}$. Ct. 2487 n.8.

15. U.S. CoNST. amend. XIV, \& 1. See CuRRIE 475. The two clauses also differ with respect to their historical purpose, see text accompanying note $74 \mathrm{infra}$, and their standard of review, see text accompanying notes 75-81 infra.

16. "No State shall make or enforce any law which shall abridge the privileges or immunities of citizens of the United States ...." U.S. ConST. amend. XIV, \& 1 .

17. The clause, however, has never operated to restrain any state legislation in its one hundred year history. See, e.g., The Slaughterhouse Cases, 83 U.S. (16 Wall.) 36 (1872). See also W. LOCKHART, Y. Kamisar \& J. Choper, supra note 13, at 520. But cf. Edwards v. California, 314 U.S. 160, 178, 182 (1941), in which both Justices Douglas and Jackson in concurring opinions stated that the right to move freely from state to state is an incident of national citizenship. The interstate commerce clause, id. at 160 , and the fifth and fourteenth amendment due process clauses, W. LOCKHART, Y. KAMISAR \& J. CHOPER, supra note 13, at 520-21, have assumed the function of the fourteenth amendment privileges and immunities clause.

Hereinafter, mention of "the privileges and immunities clause" refers to that of article IV.

18. Toomer v. Witsell, 334 U.S. 385,395 (1948).

19. Corfield v. Coryell, 6 Fed. Cas. 546, 551 (C.C.E.D. Pa. 1823). These fundamental rights are similar to those known as "natural rights." See TRIBE 405-07.

20. The literal language of the clause refers to "all privileges and immunities." The Articles $\Delta$ of Confederation version had a similar provision:

The better to secure and perpetuate mutual friendship and intercourse among the people of the different States in this Union, the free inhabitants of these States, paupers, vagabonds and fugitives from justice excepted, shall be entitled to all privileges and immunities of free citizens in the several States....

ARTICles OF CONFEDERATION art. IV. 
following the 1868 Supreme Court decision in Paul $v$. Virginia ${ }^{21}$ the latter position prevailed. $^{22}$ Recently, however, the Court has attempted to revive the fundamental right versus ordinary right distinction. $^{23}$

The Hicklin plaintiffs asserted that Alaska's local hiring plan infringed upon their right to work, ${ }^{24}$ a right which is "fundamental" under the privileges and immunities clause. ${ }^{25}$ Alaska responded that

A third view was that the privileges protected by the clause should rest upon a case-by-case view "of the particular rights asserted and denied therein." Connor v. Elliot, 59 U.S. (18 How.) 591,593 (1855).

21. 75 U.S. (8 Wall.) 168 (1868).

22. The Paul Court stated that "[i]t was undoubtedly the object of the [privileges and immunities] clause . . . to place the citizens of each State upon the same footing with the citizens of other States, so far as the advantages resulting from citizenship in those States are concerned." Id. at 180 (emphasis added). On the post-1868 acceptance of the Paul view of the scope of the clause, see Baldwin v. Fish \& Game Comm'n, 98 S. Ct. 1852, $1867-68$ (1978) (Brennan, J., dissenting); CURRIE 462-63, 523.

23. In Baldwin v. Fish \& Game Comm'n, 98 S. Ct. 1852 (1978), Justice Blackmun announced for a five-man majority that '[o]nly with respect to those 'privileges' and 'immunities' bearing upon the vitality of the Nation as a single entity must the State treat all citizens, resident and nonresident, equally." Id. at 1860 .

The purported basis for this conclusion is questionable. Justice Blackmun first cited several equal protection clause cases-Sosna v. Iowa, 419 U.S. 393 (1975); Chimento v. Stark, 353 F. Supp. 1211 (D.N.H.), aff'd, 414 U.S. 802 (1973); Dunn v. Blumstein, 405 U.S. 330 (1972); Shapiro v. Thompson, 394 U.S. 618 (1969). 98 S. Ct. at 1860. He then read the portion of the Paul opinion quoted at note 22 supra to mean that the clause protected only "fundamental rights." 98 S. Ct. at 1862. Further impairing the Baldwin Court's interpretation of the clause is the fact that even though some precedent exists for limiting the clause's protection to "fundamental rights," see note 19 supra and accompanying text, considering it to apply only to those "basic and essential activities, interference with which would frustrate the purposes of the formation of the Union," marks a departure even from this authority. The fundamental rights of citizens are not necessarily equivalent to the privileges which bear upon the vitality of the nation as a whole.

If the Baldwin Court's view of the scope of the privileges and immunities clause is valid, then the case's narrow holding that access by non-residents to a state's recreational big game hunting is not a privilege within the clause's purview seems proper.

24. $98 \mathrm{~S}$. Ct. at 2485-86; Brief of Appellants at 16, 23-24, 35 n.23, Hicklin v. Orbeck, $98 \mathrm{~S} . \mathrm{Ct}$. 2482 (1978).

25. In Corfield v. Coryell, 6 Fed. Cas. 546 (C.C.E.D. Pa. 1823), for example, it was recognized that "those privileges and immunities which are, in their nature, fundamental . . . [include t]he right of a citizen of one state to pass through, or to reside in any other state, for purposes of trade, agriculture, professional pursuits, or otherwise . . . ." Id. at 551-52.

The fundamental versus ordinary right dichotomy, of course, also plays a central role in determining the degree of scrutiny with which a court will review legislation under the equal protection clause. The right to work, however, is not a fundamental one for these equal protection clause purposes. Habron v. Epstein, 412 F. Supp. 256, 259-62 (D. Md.), affd, 429 U.S. 802 (1976). See Kotch v. Board of River Port Pilot Comm'rs, 330 U.S. 552, 556 (1947). Thus, the right to work exemplifies the proposition stated in Hicklin, 565 P.2d at 166, 168 \& n.16, that the list of fundamental rights under the privileges and immunities clause exceeds its counterpart under the equal protection clause.

The Hicklin plaintiffs also alleged a violation of their right to interstate travel. Id. at 162. This right is clearly a fundamental one, both as an historical matter under the privileges and 
the privileges and immunities clause has no application to the right to work when the desired employment relates to state disposition of its own property and, even assuming the clause is applicable, that the discrimination effected by Alaska Hire did not violate the clause under the appropriate standard of review. ${ }^{26}$

\section{A. The McCready Exception.}

Alaska's first argument has roots in the seminal case of Corfield $v$. Coryell $^{27}$ in which a Pennsylvanian challenged a New Jersey law limiting local commercial shellfishing to state fishermen. Justice Bushrod Washington, riding circuit, held that despite any infringement of the fundamental privilege to work in any state, New Jersey could limit the right to fish from New Jersey waters to its own citizens. Justice Washington's argument rested on the theory that opening up the New Jersey shellfishery to foreign exploitation would exhaust the supply of shellfish available to New Jersey citizens. ${ }^{28}$ Further, the legislature had the power to "regulate the use" of that resource for the benefit of the people of the state, since the fish were their "common property."29

$M c$ Cready v. Virginia ${ }^{30}$ is a second landmark case dealing with natural resources and the privileges and immunities clause. In $M c C r e a d y$, a nonresident challenged the state's denial of his right to plant shellfish. The plaintiff contended that the right to plant in Virginia waters-in contrast to the asserted right to extract in Corfield-did not involve any taking of state property. ${ }^{31}$ But Chief Justice Waite chose not to rest the Court's decision on Corfield's deple-

immunities clause, Corfield v. Coryell, 6 Fed. Cas. 546, 552 (C.C.E.D. Pa. 1823), and for contemporary purposes under the equal protection clause. Shapiro v. Thompson, 394 U.S. 618, 629, 634 (1969). However, the domicile preference in Alaska Hire does not impair this right. A domicile requirement does not discourage interstate migration as does a durational residency test with the latter's prospect of ineligibility for benefits, such as voting and public assistance, from the receiving state during a "waiting period." Hicklin, 565 P.2d at 166. For a non-Alaskan seeking work in the state-connected oil and gas industry, the burden imposed by Alaska Hire's domicile requirement is only that he must forfeit his claim to benefits in his former state, presumably to receive similar benefits from Alaska without delay. Id at 171. The immigrant would have to pay applicable Alaska taxes, but presumably his tax liability in his former state would decrease or cease altogether. Id. See also ALASKA STAT. \$ 38.40.090(I)(C)-(D) (1977), quoted at note 6 supra. For additional discussion of whether durational and nondurational residency preferences violate rights, other than the right to work, that are protected by the privileges and immunities and equal protection clauses, see note 101 infra.

26. Brief of Appellees at 16-35, Hicklin v. Orbeck, 98 S. Ct. 2482 (1978).

27. 6 Fed. Cas. 546 (C.C.E.D. Pa. 1823).

28. Id. at 552 .

29. Id. Justice Washington's argument, however, was purely dictum. See CURRIE 461.

30. 94 U.S. 391 (1876).

31. Id. at $392-93$. 
tion of resources rationale. Instead, he grounded his opinion on the mere fact that the citizens of Virginia, and not the citizens of all free governments, owned the Virginia tidewaters and their beds. Thus, Virginians had "the power to dispose of [those areas] as they saw fit." ${ }^{32}$

McCready was not to be the last word, however. Some seventy years later, the Court in Toomer v. Witsell ${ }^{33}$ questioned McCready, although it did not expressly overrule the case. Toomer struck down a prohibitively high license fee for out-of-state commercial fishermen as violative of the privileges and immunities clause. The Toomer Court's language appears strongly critical of the proprietary interest justification for state discrimination: "The whole ownership theory, in fact, is now generally regarded as but a fiction expressive in legal shorthand of the importance to its people that a State have power to preserve and regulate the exploitation of an important resource."34

In light of the Toomer Court's strong intimation that "the McCready exception, if such it be"35 was no longer viable, ${ }^{36}$ Toomer arguably reduced $\mathrm{McCready}$ from a complete exception to the privileges and immunities clause to an affirmation that state authority in dealing with natural resources constitutes only a "legitimate government interest." 37 This authority would be subject to judicial review to insure its rational exercise. ${ }^{38}$

32. Id. at 396.

33. 334 U.S. 385 (1948).

34. Id. at 402 .

35. Id.

36. The passages disapproving McCready are admittedly dicta; the Toomer Court distinguished McCready without overruling it. See text accompanying note 33 supra. McCready involved nonmigratory fish found in state waters. The statute in Toomer attempted through discriminatory licensing fees to regulate the taking of migratory fish in the marginal seas. At least prior to the 1953 Submerged Lands Act, 43 U.S.C. $\$ \S 1301-1343$ (1970), states could not have McCready-type ownership of such fish. See Commonwealth v. Westcott, 344 N.E.2d 411, 412-13 (Mass. 1976), affd sub nom. Massachusetts v. Westcott, 431 U.S. 322 (1977).

The Westcott case involved a statute similar to that in Toomer, although the limitation on nonresident fishing was absolute rather than just a financial disincentive. The dissent in the Massachusetts Supreme Judicial Court argued that the federal Submerged Lands Act gave states title to the first three miles of their marginal seas and to the fish swimming therein, thus extending a still viable $\mathrm{McCready}$ ownership principle to state regulation in that area. 344 N.E.2d at 414-18 (Reardon, J., dissenting). The United States Supreme Court avoided the Submerged Land Act issue-and that of the continued status of the McCready exception-by finding that federal licensing laws prevented states from discriminating against federally licensed boats, such as Westcotl's, in state waters. Massachusetts v. Westcott, 431 U.S. 322, 323 (1977).

37. See Brief for the Respondent at 18-19, Massachusetts v. Westcott, 431 U.S. 322 (1977); TrIBE 409.

38. On the appropriate standard of judicial review, see text accompanying notes 75-81 infra.

An alternative interpretation is that Toomer merely recast $M c C r e a d y$ into a contemporary semantic mold. That is, to support the continued nonreviewability of state discrimination relating to fish and game, Toomer substituted the police power (the "power to preserve, regulate, and 
Recent Supreme Court dicta lend credence to this position. In Kleppe v. New Mexico, ${ }^{39}$ the state of New Mexico asserted that the federal Wild and Free-Roaming Horses and Burros Act ${ }^{40}$ unconstitutionally inferfered with the power of the states to seize wild animals within state borders. ${ }^{41}$ The Court upheld the federal statute as a valid exercise of the article IV property clause ${ }^{42}$ and as paramount to any state arguments under $\mathrm{McCready}{ }^{43}$ In responding to such arguments, the Court chose to adopt the post-Toomer interpretation of McCready: absent federal action, states still had "broad trustee and police powers over wild animals within their jurisdiction." 44

The recasting of $M c C r e a d y$ became even clearer in Douglas $v$. Seacoast Products, Inc. ${ }^{45}$ In that case the Court invalidated on federal preemption grounds ${ }^{46}$ a Virginia law prohibiting vessels owned by nonresidents from fishing in Chesapeake Bay. In dictum responding to Virginia's McCready-based claim that state ownership of the fish could justify the discrimination, the Court stated that "it is pure fantasy to talk of 'owning' wild fish, birds, or animals. . . . Under modern analysis, the question is simply whether the State has exercised its police power in conformity with the federal laws and Constitution." ${ }^{.47}$ Finally,

exploit a natural resource") for the more antiquated "ownership theory." Alleyne, Constitutional Restraints on the Preferential Hiring of Alaskan Residents for Oil Pipeline Construction, 2 U.C.L.A.Alas. L. Rev. 1, 6-7 (1972).

39. 426 U.S. 529 (1976).

40. 16 U.S.C. $\$ \S 1331-1340$ (Supp. V 1975).

41. The Act prohibited state seizures, such as the one in question, that took place on federal lands. 426 U.S. at 533-34.

On the application of $M c$ Cready to resources other than fish, see notes 55, 57 infra and text accompanying notes $55-57$ infra.

42. "The Congress shall have Power to dispose of and make all needful Rules and Regulations respecting the Territory or other Property belonging to the United States . ..." U.S. ConsT. art. IV, $\S 3$.

43. 426 U.S. at 545. The Court has also held the exercise of federal power under the treaty clause, U.S. CoNST. art. $2, \S 2$, and the necessary and proper clause, U.S. CoNST. art. $1, \S 8$, to be paramount to a $M c$ Cready-type ownership argument. See Missouri v. Holland, 252 U.S. 416 (1920) (treaty protects birds despite state objections). Of course, the fact that constitutionally valid federal action can prevail over the $M c$ Cready doctrine is not determinative of the doctrine's viability when, as in Hicklin, no federal conflicts exist. See Baldwin v. Fish \& Game Comm'n, 98 S. Ct. 1852, 1861 (1978).

On the relationship between $\mathrm{McCready}$ and the negative implications of the interstate commerce clause, see note 57 infra.

44. 426 U.S. at 545 (emphasis added).

45. 431 U.S. 265 (1977).

46. See note 43 supra.

47. 431 U.S. at 284-85. Dissenting Justices Rehnquist and Powell, however, supported at least a modified $M c C r e a d y$ ownership theory: "States have a substantial proprietary interest-sometimes described as "common ownership' . . . in the fish and game within their boundaries . . . whether or not [this interest] rise[s] to the level of a traditional property right." 431 U.S. at 287-88 (Rehnquist, J., dissenting). 
in Hicklin, Justice Brennan spoke for a unanimous Court in confirming that

[r]ather than placing a statute completely beyond the [privileges and immunities clause], a State's ownership of the property with which the statute is concerned is a factor-although often the crucial factor-to be considered in evaluating whether the statute's discrimination against noncitizens violates the Clause. ${ }^{48}$

Aside from its resting on an anachronistic ownership theory, the $M c C r e a d y$ exception to the privileges and immunities clause has a second major flaw. The McCready statute did not restrict shellfish to Virginians; nonresidents could purchase, but could not plant, Virginia shellfish. ${ }^{49}$ Similarly, in Corfield nothing prevented Pennsylvanians from buying, as opposed to extracting, fish in New Jersey. ${ }^{50}$ Thus, the common reading of $\mathrm{McCready}$ - that states can limit their natural resources to state uses ${ }^{51}$-mischaracterizes the case. In Corfield and McCready, New Jersey and Virginia, respectively, in effect sought to preserve employment in the extracting and planting of shellish for their citizens by closing their fisheries to nonresident fishermen. ${ }^{52}$ It thus becomes evident that the "common property" basis of the McCready exception ${ }^{53}$ is illusory. Regardless of whether fish and game can constitute the common property of the state, it is ludicrous to contend that a state can "own" employment in a given industry. Hence, when the restrictions in Corfield and $M c$ Cready are seen for what they are-attempts to limit employment to state citizens-it becomes apparent that they lack a justifying rationale.

Assuming arguendo that the $\mathrm{McCready}$ ownership rationale has

In dictum in a subsequent case, fellow Nixon appointees Justice Blackmun and Chief Justice Burger also adopted a position more moderate than that of the Douglas majority - of which they were a part. Their view was that McCready continued to supply a state with a "special interest," presumably one greater than the police power, in preferring its own citizens with respect to wildlife found in that state. Baldwin v. Fish \& Game Comm'n, 98 S. Ct. 1852, 1862 (1978) (Blackmun, J., for the Court); id. at 1864-65 (Burger, C.J., concurring). See also note 52 infra. Justices Stevens and Stewart joined in Justice Blackmun's Baldwin opinion, again notwithstanding their membership in the Douglas majority responsible for the extremely critical view of $M c C r e a d y$ quoted infra.

48. $98 \mathrm{~S}$. Ct. at 2490 .

49. 94 U.S. at $392-93$.

50. This fact impairs Justice Washington's theory that the Corfield statute prevented the depletion of the supply of shellfish available to New Jersey citizens. See text accompanying note 28 supra.

51. See, e.g., Hicklin, 565 P.2d at 172 (Boochever, C.J., dissenting in part).

52. Approaching this interpretation is the Supreme Court's citation of McCready as representative of a "special-public-interest doctrine" that permits a state to "limit the right of noncitizens to exploit a State's natural resources." Sugarman v. Dougall, 413 U.S. 634, 644 n.11 (1973). On other aspects of the special public interest doctrine, see text accompanying notes 146-60 infra.

53. See text accompanying note 32 supra. 
some remaining vitality, ${ }^{54}$ one question raised by Alaska Hire is whether $\mathrm{McCready}$ would extend to inanimate state resources such as oil. ${ }^{55}$ The Hicklin Court concluded that it would, since the Alaska Statehood Act ${ }^{56}$ gave the state full title to minerals below state-selected land. ${ }^{57}$

The major problem with applying $M c$ Cready, however, is that Alaska Hire's restrictions concern employment rather than control over a natural resource. ${ }^{58}$ Since courts are unlikely to consider employment

54. As pointed out in note 47 supra and text accompanying notes 47-48 supra, the current dicta of the Supreme Court are conflicting on this point.

55. The Court lacked the guidance of precedent on this issue. The courts that have not rejected McCready's ownership principle altogether have held that Toomer preserved McCready's application to shellfish, which are nonmigratory. See, e.g., State v. Norton, 335 A.2d 607, 615 (Me. 1975). See also cases cited in Commonwealth v. Westcott, 344 N.E.2d 411, 412-13 (Mass. 1976), affd sub nom. Massachusetts v. Westcott, 431 U.S. 322 (1977).

The exception has on occasion been extended to animals. Compare Baldwin v. Fish \& Game Comm'n, 98 S. Ct. 1852, 1864-65 (1978) (Burger, C.J., concurring) (Montana has "special interest" in preferring its own citizens in allocating access to elk found primarily within that state) and Patstone v. Pennsylvania, 232 U.S. 138, 145-46 (1914) (Pennsylvania allowed to prevent aliens from owning guns for the purpose of killing commonly owned wild game within the state) and Geer v. Connecticut, 161 U.S. 519, 530 (1896) (Connecticut's "common ownership" of game birds allowed its legislature to prohibit their transportation out of state) with Schakel v. State, 513 P.2d 412,414 (Wyo. 1973) (state not the owner of deer and thus not free to prohibit nonresidents from hunting without a guide) and Missouri v. Holland, 252 U.S. 416, 434 (1920) (treaty clause case; state not the owner of migratory birds: "To put the claim of the State upon title is to lean upon a slender reed").

56. Pub. L. No. $85-508,72$ Stat. 339 (1958) (codified at 48 U.S.C. following $§ 5$ (1970)).

57. Id. $\S 6(\mathrm{i})$. See 98 S. Ct. at 2489 \& n.11. Similarly, the Alaska Supreme Court had held that the state's ownership of oil and gas is "less of a legal fiction than it is with respect to fish and game." 565 P.2d at 168.

The objection to this view is that oil can be as much a migratory and thus nonpossessory resource as free-swimming fish, which, after Toomer, are accepted as being outside of $M c C r e a d y$ 's reach. See note 36 supra. That is, as the Supreme Court itself once held,

[p]etroleum gas and oil . . . belong to the owner of the land, and are part of it, so long as they are on it or in it, or subject to his control, but when they escape and go into other

land, or come under another's control, the title of the former owner is gone.

Brown v. Spilman, 155 U.S. 665, 669-70 (1895). In fact, courts have often compared ownership of natural gas and oil to that of migratory wild animals. See, e.g., Westmoreland \& Cámbria Natural Gas Co. v. DeWitt, $130 \mathrm{~Pa}$. 235, 249, 18 A. 724, 725 (1889). Coal, which has a fixed situs, provides a better example of a mineral resource subject to possession and ownership.

In any case, under the holding of Foster-Fountain Packing Co. v. Haydel, 278 U.S. 1 (1928), Alaska presumably relinquishes any ownership interest in its oil and gas by putting these articles into interstate commerce. Foster-Fountain denied Louisiana the power under the commerce clause to require local processing of state-owned shrimp. The Supreme Court held that putting the shrimp into interstate commerce "put an end to the trust upon which the State is deemed to own or control the shrimp for the benefit of its people." Id. at 13. Cf. Geer v. Connecticut, 161 U.S. 519, 530, 532 (1896) ("common ownership" of wild fish and game a valid basis for prohibiting their transportation out-of-state).

58. See Hicklin, 565 P.2d at 172-73 (Boochever, C.J., dissenting in part). For mention of the probable interstate commerce clause consequences had Alaska attempted to restrict its oil and gas for state use, see id. at 172 n.5; note 127 infra. 
the "common property" of the state, ${ }^{59}$ it is difficult to justify the $M c C r e a d y$ exception as applied to barriers to nonresident employment.

One response is that Alaska's local hiring plan "deals with" 60 or, in Corfield terms, "regulates the use of" st state-owned oil and gas. The purported link between employment and the resource is the requirement in the Alaska Hire statute that the work-generating activity take place on or be directly related to property acquired under state oil and gas leases. ${ }^{62}$

Clearly, this link has some importance. Were Alaska to extend local hiring to all private employment in the state, such a statute plainly would exceed the scope of the resource-related McCready exception and thus would be subject to review under the privileges and immunities clause. Following the analysis presented below, the statute would fall. ${ }^{63}$ On the other hand, neither the privileges and immunities clause nor the equal protection clause prevents a state from preferring its own residents for public employment; ${ }^{64}$ the $M c$ Cready exception is not needed to save such a preference.

Because of the link to state-owned resources, Alaska Hire falls in between these two extremes. The Supreme Court in Hicklin found the connection between Alaska-owned oil and the employment covered under Alaska Hire "sufficiently attenuated" so as to prevent that connection from supplying a basis for discrimination against nonresidents. ${ }^{65}$ Indeed, Justice Brennan characterized the Act as "an attempt to force virtually all businesses that benefit in some way from the economic ripple effect of Alaska's decision to develop her oil and gas resources to bias their employment practices in favor of the State's

59. See text accompanying notes 52-53 supra.

60. Hicklin, 565 P.2d at 169.

61. 6 Fed. Cas. 546, 552 (C.C.E.D. Pa. 1823).

62. AlASKA STAT. $\$ 38.40 .050($ a) (1977), quoted at note 1 supra.

63. Such a statute would effect a much wider discrimination than the present Alaska Hire Act, which in itself violates the privileges and immunities clause. See text accompanying notes 93-96 infra. Moreover, interstate commerce clause objections would quickly arise to such a widesweeping employment preference. See text accompanying note 165 infra. See also Truax v. Raich, 239 U.S. 33 (1915) (Arizona law excluding aliens from most private employment within the state violates equal protection clause); Alleyne, supra note 38, at 8.

64. See State v. Wylie, 516 P.2d 142, 150 (Alas. 1973) (one year residency requirement for state employment struck but bona fide residency test permissible). See also McCarthy v. Philadelphia Civil Serv. Comm'n, 424 U.S. 645 (1976), in which a unanimous Court upheld against the challenge of a New Jersey resident a regulation requiring bona fide Philadelphia (and, thus, Pennsylvania) residence for city employment. See note 163 infra and accompanying text. But $c$. Donnelly v. City of Manchester, 111 N.H. 50, 274 A.2d 789 (1971) (nondurational city residency requirement for city employment violated state constitution's protection of "right to live where one chooses.").

65. $98 \mathrm{~S}$. Ct. at 2490. 
residents." Certainly this interpretation makes it difficult to visualize the state as "dealing with" or "restricting the use of" its common property. In any event, even if under an extant $\mathrm{McCready}$ doctrine an "attenuated" link to state-owned resources could insulate nonresident employment discrimination from privileges and immunities clause objections, the interstate commerce clause might not permit such discrimination. 67

\section{B. Application of the Privileges and Immunities Clause to Alaska Hire.}

Assuming that the $\mathrm{McCready}$ doctrine does not provide Alaska Hire with an exception to privileges and immunities clause review, the question becomes whether the clause itself tolerates the discrimination effected by Alaska's domicile hiring preference. ${ }^{68}$ Toomer states the relevant test:

[The privileges and immunities clause] bar[s] discrimination against citizens of other states where there is no substantial reason for the discrimination beyond the mere fact that they are citizens of other States. But it does not preclude disparity of treatment in the many situations where there are perfectly valid independent reasons for it. Thus the inquiry in each case must be concerned with whether such reasons do exist and whether the degree of discrimination bears a close relation to them. The inquiry must also, of course, be conducted with due regard for the principle that the States should have considerable leeway in analyzing local evils and in prescribing appropriate cures. ${ }^{69}$

At least one commentator has interpreted the Toomer test as invoking one of the two standards of review-"strict scrutiny" or "rational basis"-employed in equal protection clause cases, the applicable standard depending upon the facts in each case. ${ }^{70}$ Indeed, some cases involving nondurational residency requirements have been reviewed exclusively under the equal protection clause. ${ }^{71}$

66. Id. at 2491 .

67. See text accompanying notes 107, 125-142 infra.

68. See, e.g., State v. Kemp, 73 S.D. 458, 462-63, 44 N.W.2d 214, 216-17 (1950), appeal dismissed, 340 U.S. 923 (1951) (McCready ownership theory questioned as applied to wild game; state power to prohibit issuance of nonresident hunting licenses subjected to review under the privileges and immunities clause).

69. 334 U.S. at 396.

70. See CURRIE 475.

71. These cases, however, differ from Hicklin in two respects. In one group of cases the plaintiffs originally challenged durational residency requirements. Although the plaintiffs had not been state residents long enough to satisfy these waiting periods, they had at least moved into, and were most likely domiciled in, the defendant state. Thus, the equal protection clause, which prohibits a state from discriminating against persons "within its jurisdiction," constituted the appropriate provision for purposes of judicial review. After invalidating the waiting periods, the 
Yet the privileges and immunities and equal protection clauses serve distinct purposes. The equal protection clause prohibits state discrimination against persons "within its jurisdiction;"72 the privileges and immunities clause proscribes discrimination against out-ofstaters. $^{73}$ In addition, the equal protection clause has historically served to curb official racial prejudice, while the privileges and immunities clause has functioned to smooth economic relations among the states. ${ }^{74}$

Thus, the better view is that judicial analysis under the two clauses should not be equated automatically. ${ }^{75}$ First, the Toomer test does not inquire into the nature of any classifications created or rights restricted by the contested statute as does the two-tiered equal protection (and due process) system of review. ${ }^{76}$ The classic privileges and immunities clause test stated in Toomer is unitary-regardless of the class or right allegedly harmed, the applicable standard remains one of permitting state discrimination only when it bears a "close relation" to a "substantial reason" for discriminating. ${ }^{77}$ Second, the degree of judicial deference that must be accorded a statute challenged under the privileges and immunities clause places the Toomer test in between the two

courts in these cases went on to speak approvingly of domicile requirements without changing their reviewing standard to that of the privileges and immunities clause. See Dunn v. Blumstein, 405 U.S. 330, 343 (1972) (voting); Shapiro v. Thompson, 394 U.S. 618, 636 (1969) (welfare); State v. Wylie, 516 P.2d 142, 150 (Alas. 1973) (state employment). See also Comment, Durational Residency Requirements: The Alaskan Experience, 6 U.C.L.A.-ALAS. L. REv. 50, 54 (1976).

Review of nondurational residency requirements took place under the equal protection clause in at least two other cases because employment requirements were for city rather than state residence. The privileges and immunities clause applies only to discrimination against out-of-staters. See McCarthy v. Philadelphia Civil Serv. Comm'n, 424 U.S. 645 (1976); Donnelly v. City of Manchester, 111 N.H. 50, 274 A.2d 789 (1971). However, as indicated in note 64 supra, McCarthy effectively involved discrimination against out-of-staters because a resident of New Jersey contested a Philadelphia residence requirement.

The Hicklin plaintiffs raised both privileges and immunities and equal protection claims, but the Supreme Court found it unnecessary to reach the latter. $98 \mathrm{~S}$. Ct. at 2492 n.19.

72. U.S. ConsT. amend. XIV, § 1.

73. U.S. Const. art. IV, \& 2. See also CuRRIE 475. See text accompanying notes 12-15 supra.

74. See Shapiro v. Thompson, 394 U.S. 618, 659 (1969) (Harlan, J., dissenting) (equal protection clause); Toomer v. Witsell, 334 U.S. 385, 395-96 (1948) (privileges and immunities clause).

75. See Doe v. Bolton, 410 U.S. 179, 200 (1973); TRIBE 409-12.

76. Under the equal protection clause, reviewing courts will apply "strict scrutiny" to a statute which allegedly discriminates against a "suspect" class or which impairs a "fundamental" right. In the absence of such allegations, courts will examine the statute under the more deferential "rational basis" test. See San Antonio Ind. School Dist. v. Rodriguez, 411 U.S. 1, 17 (1973). See also text accompanying notes 78-80 infra.

77. See quotation in text accompanying note 69 supra. In Doe v. Bolton, 410 U.S. 179, 200 (1973), for example, the fact that the right in question-a woman's right to have an abortion-is fundamental for equal protection clause purposes did not alter the privileges and immunities clause standard applied. See Baldwin v. Fish \& Game Comm'n, 98 S. Ct. 1852, 1869 n.4 (1978) (Brennan, J., dissenting). See text accompanying notes 86-89 infra. 
standards of review used under the equal protection clause. Toomer's requirement of a "substantial" or "valid" reason for state discrimination falls short of the "compelling" justification necessary under strict equal protection clause scrutiny. ${ }^{78}$ On the other hand, Toomer's literal insistence upon a "close relation"-and, interpretatively, its requirement of the least possible disparity ${ }^{79}$-between the purpose and effect of the discrimination is more stringent than the corresponding demand of the relaxed form of equal protection review that the statute bear only an "arguably rational" relation to the asserted governmental interest. ${ }^{80}$ The Toomer standard does, however, resemble the "intermediate" level of equal protection clause scrutiny that the Supreme Court has occasionally applied in gender-discrimination cases. ${ }^{81}$

In applying its own "close relation" test, the Toomer Court stressed that the privileges and immunities clause would only tolerate differential license fees tailored so as merely to compensate the state for any added enforcement burden that nonresident fishermen might impose. Thus, the Court invalidated the highly discriminatory license fees at issue as going beyond what was necessary to meet this enforcement function. ${ }^{82}$

Subsequent privileges and immunities clause cases, although relatively few in number, have followed this holding of Toomer. Together they show that Toomer's requirement of a "close relation" between the ends and means of state discrimination defeats a statute that sweeps too

78. See TRIBE 411 \& n.17.

79. $Y d .410$.

80. See City of New Orleans v. Dukes, 427 U.S. 297, 303, 305 (1976). Seemingly confirming the fact that it was applying a relaxed reviewing standard, the Dukes Court overruled Morey v. Doud, 354 U.S. 457 (1957), the only modern case in which the Supreme Court had invalidated an economic classification. 427 U.S. at 306.

81. See Craig v. Boren, 429 U.S. 190 (1976); TrIBE 411 n.17 and sources cited therein. In Craig the Supreme Court found violative of the equal protection clause an Oklahoma statute prohibiting the sale of $3.2 \%$ beer to females under the age of 18 and males under age 21 . The standard applied was that an allegedly gender-discriminating statute must bear a "substantial relation" to an "important" state objective. 429 U.S. at 197. Compared to the second half of this requirement, the Toomer test seems no more stringent, especially if one borrows the "valid [meaning, presumably, 'permissible'] reason" as opposed to the "substantial reason" language from Toomer. On the other hand, to the extent that Toomer's "close relation" terminology means that the state must use the least restrictive alternative to promote its objective, see text accompanying note 79 supra, the Toomer standard seems more demanding than intermediate scrutiny's "substantial relation" requirement.

For criticism of the multi-tiered equal protection clause approach that Craig sanctions, see 429 U.S. at 210-11 n.* (Powell, J., concurring); id. at 211-12 (Stevens, J., concurring); id. at 217, 220-21 (Rehnquist, J., dissenting).

Professor Tribe contends that the 1948 formulation of the Toomer test greatly influenced the development of equal protection clause standards. TRIBE 410.

82. 334 U.S. at 399. 
broadly. ${ }^{83}$ Some of these cases, for example, have focused on Toomer's suggestion that only when noncitizens constitute "a peculiar source of the evil at which the statute is aimed"84 might the desired relation exist. ${ }^{85}$

Prior to Hicklin, the only recent Supreme Court application of the Toomer test came in two paragraphs of Doe v. Bolton. ${ }^{86}$ In that case the Court invalidated a Georgia law permitting abortions only when the mother was a Georgia resident. ${ }^{87}$ Speaking for the majority, Justice Blackmun conceded that the residency requirement could have "some relationship" to the availability of medical care for a Georgia patient. $^{88}$ Nevertheless, "some relationship" to the state interest was not a sufficiently close fit; the Court invalidated the residency requirement because the evidence did not show that Georgia facilities were filled to capacity in caring for residents. Moreover, to the extent that the policy of preserving state-supported medical care for Georgians formed the justification for the residency test, the statute's additional coverage of private hospitals and privately retained physicians rendered it unnecessarily and, hence, impermissibly restrictive. ${ }^{89}$

The application of the Toomer test to Alaska Hire begins with the observation that the Act purports to upgrade human resources and reduce unemployment. ${ }^{90}$ These state interests have been found to be not only permissible, but also compelling justifications for classification. ${ }^{91}$

83. See Mullaney v. Anderson, 342 U.S. 415, 417-18 (1952); American Commuters Assoc. v. Levitt, 279 F. Supp. 40, 48 (S.D.N.Y. 1967), affd, 405 F.2d 1148 (2d Cir. 1969); Edwards v. Leaver, 102 F. Supp. 698, 702 (D.R.I. 1952).

84. 334 U.S. at 398.

85. Compare Edwards v. Leaver, 102 F. Supp. 698, 702-03 (D.R.I. 1952) (no local evils caused by nonresidents which might otherwise justify statute denying them commercial fishing licenses) with State v. Kemp, 73 S.D. 458, 462-63, 44 N.W.2d 214, 216-17 (1950), appeal dismissed, 340 U.S. 923 (1951) (statute denying licenses to nonresident hunters of migratory waterfowl upheld since such hunters constituted a peculiar source of excessive hunting; no further inquiry into whether legislature could have prescribed a less discriminatory remedy).

The Hicklin Court suggested that even when a state demonstrates that nonresidents constitute a peculiar source of the evil in question, the discrimination produced by the challenged statute must still bear a "substantial relation" to that evil. See $98 \mathrm{~S}$. Ct. at 2488. See text accompanying notes 102-07 infra.

86. 410 U.S. 179,200 (1973).

87. Id. at 184,200 . The Supreme Court found that the additional conditions that only a licensed, accredited hospital could perform the abortion, and then only with both the advance approval of a hospital "abortion committee" and a written concurrence by two other Georgia physicians, infringed the right to privacy. Id. at 192-200.

88. Id. at 200 .

89. Id. See Tribe 410.

90. See notes 3-4 supra and accompanying text.

91. State v. Wylie, 516 P.2d 142, 149-50 (Alas. 1973). Notwithstanding the explicit statements of policy in the Alaska Hire statute, the Alaska trial court in Hicklin found the Act an attempt to solve "problems that may be typified as social, racial, educational, and economic." 565 
Thus, they would clearly satisfy Toomer's requirement that a "valid" or "substantial" reason for state discrimination exist. ${ }^{92}$

The more difficult question is whether the means employed by Alaska Hire bear a "close relation" to its objectives. Since under local hiring jobs go first to bona fide Alaskans, the statute would seem to relate rationally to upgrading human resources and reducing unemployment. However, it has already been shown that the "close relation" test demands not only an "arguably rational" relation but also, quite probably, use of the least discriminatory plan available. ${ }^{93}$

Under this standard Alaska Hire runs afoul of the privileges and immunities clause. The program proves to be an overly restrictive attempt to lower unemployment in that it occasionally discriminates against out-of-staters for the sake of preferring employed residents. ${ }^{94}$ As Justice Brennan noted, "[a] highly skilled and educated resident who has never been unemployed is entitled to precisely the same preferential treatment as the unskilled, habitually unemployed Arctic Eskimo enrolled in a job training program."9s Alaska could more directly ameliorate its unemployment problem by limiting its hiring preference to unemployed Alaskans. ${ }^{96}$ Although the Supreme Court questioned the permissibility even of this type of preference, ${ }^{97}$ the modification would reduce the current discrimination against nonresidents by elevating them to an equal status (albeit behind that of unemployed Alaskans) with employed residents for jobs covered by the Act.

An additional approach to attacking unemployment directly-one that Alaska in fact has adopted-would be to provide job training for unskilled, unemployed Alaskans. ${ }^{98}$ Manpower programs could include preparation for oil- and gas-related work. Presumably, the state

P.2d at 169. Considering such an attempt a valid state pursuit under the privileges and immunities clause, the trial court upheld the Act. Id. at 169. See note 9 supra. The Alaska Supreme Court also ignored the plain wording of the Act and deemed the purpose of the legislation the impermissible one of "economic protectionism." Nevertheless, it preserved the statute on the basis of the McCready exception. 565 P.2d at 169. The United States Supreme Court accepted the purpose of the Act as the reduction of unemployment, $98 \mathrm{~S}$. Ct. at 2485 , and did not question the substantiality of that purpose.

92. See text accompanying note 78 supra.

93. See text accompanying notes 79-80 supra.

94. Hicklin, 565 P.2d at 164. Contra, People ex rel. Holland v. Bleigh Constr. Co., 61 Ill. $2 \mathrm{~d}$ 258, 273, 335 N.E.2d 469, 478-79 (1975) (preference for Illinois laborers on public works projects, including those undertaken by private employers, bears a "close relation" to the goal of providing employment for residents).

95. Hicklin, $98 \mathrm{~S}$. Ct. at 2489.

96. Hicklin, 565 P.2d at 164-65.

97. Hicklin, $98 \mathrm{~S}$. Ct. at 2489.

98. Hicklin, 565 P.2d at 164. 
could then make its hiring preference applicable to recent trainees. ${ }^{99}$

Reliance on an unemployed-resident hiring preference that extends to those Alaskans who, because of their social circumstances, require special training to become job-competitive, represents both a narrowly tailored and an effective approach to the reduction of unemployment. ${ }^{100}$ Nondomiciliaries would still encounter some discrimination under the revision, but even Toomer does not preclude "disparity of treatment in the many situations where there are perfectly valid independent reasons for it [and where] the degree of discrimination bears a close relation to them." 101

Aside from the statute's failure to meet the "close relation" test, the Supreme Court found that Alaska Hire fell short of what it considered a second Toomer standard. ${ }^{102}$ Nonresidents, the Court deter-

99. Id. at 165 .

100. See text accompanying notes $96-97$ supra.

101. 334 U.S. at 396.

It seems quite possible that the suggested revision would not have been necessary and that the presently constituted Alaska Hire Act could have withstood constitutional scrutiny had it been reviewed under the equal protection clause. (For the argument that the privileges and immunities clause is more appropriate to test the constitutionality of domicile requirements, see note 71 supra and text accompanying notes 72-74 supra.) The first question is whether a court should apply a strict or a lenient standard of review. The application of strict judicial scrutiny requires the presence of either discrimination against a suspect class or impairment of a fundamental right. San Antonio Ind. School Dist. v. Rodriguez, 411 U.S. 1, 17 (1973). While local hire classifies according to residency, courts have not elevated residency-as opposed to alienage- to a suspect class. See Hicklin, 565 P.2d at 167 (citing Matthews v. Diaz, 426 U.S. 67, 84-87 (1976)); TRIBE 411 . Nor has the right to work asserted by the Hicklin plaintiffs been judicially identified as a fundamental right. Habron v. Epstein, 412 F. Supp. 256, $259-62$ (D. Md.), affd, 429 U.S. 802 (1976). See Kotch v. Board of River Port Pilots Comm'rs, 330 U.S. 552, 556 (1947).

The Hicklin plaintiffs also sought protection of their right to interstate travel, which is well established to be a fundamental right. See Shapiro v. Thompson, 394 U.S. 618, 629, 634 (1969). The Supreme Court, however, has not chosen to apply strict scrutiny to nondurational domicile requirements, thus implying that they do not impair the right to travel. See McCarthy v. Philadelphia Civil Serv. Comm'n, 424 U.S. 645 (1976). See also Aranson v. Ambrose, 479 F.2d 75, 77 78 (3d Cir.), cert. denied, 414 U.S. 854 (1973); TRIBE $410 \mathrm{n} .10$ and sources cited therein. In fact, recent Supreme Court cases suggest that even a durational residency requirement may not infringe the right to travel unless the "waiting period" in question deprives the traveler of a "necessity of life." See, e.g., Memorial Hosp. v. Maricopa County, 415 U.S. 250, 259 (1974); Comment, supra note 71 , at 57 .

Since Alaska Hire's domicile preference does not create suspect classifications nor impair fundamental rights, its equal protection clause review would take place under the more deferential standard. That test is whether the challenged statute bears an arguably rational relation to a legitimate state interest. City of New Orleans v. Dukes, 427 U.S. 297, 303, 305 (1976). That Alaska Hire promotes permissible government objectives in a "rational" manner has already been noted. See text accompanying notes 90-93 supra.

Professor Tribe has observed that, in general, nondurational residency requirements will violate the privileges and immunities clause under the Toomer test but will satisfy the rational basis standard of the equal protection clause. TRIBE 411-12.

102. As noted at note 91 supra, the Court ostensibly assumed that Alaska Hire satisfied an initial Toomer test of promoting a substantial state interest. 
mined, did not constitute a "peculiar source of the evil"- unemployment-at which the statute was aimed. ${ }^{103}$ Rather, the Court found the major cause of Alaska's high unemployment to be the remoteness of many residents, particularly Eskimos and Indians, from educational, employment, and job training opportunities. ${ }^{104}$ Without questioning this factual observation, the use of the "peculiar source of the evil" test to probe further into the nexus between legislative ends and means must nevertheless be noted. ${ }^{105}$ Hicklin apparently marks a departure from the more general, single-step inquiry into the tailoring of means and ends of Doe and lower court cases. ${ }^{106}$

\section{The Interstate Commerce Clause}

Independent of its link to resources which may be owned by the state or of its status under the privileges and immunities clause, a domicile employment preference may conflict with the negative implications of the interstate commerce clause. ${ }^{107}$ "Negative implications" refers to the fact that the commerce clause not only grants Congress plenary power to control interstate commerce ${ }^{108}$ but also forbids states from placing "undue" or "discriminatory" burdens on that commerce. ${ }^{109}$

In determining what constitutes an undue burden on commerce, the Supreme Court has looked either to the directness of a statute's effects on interstate commerce or to whether those effects outweigh local interests. ${ }^{110}$ The most recent Supreme Court standard, announced in Pike v. Bruce Church, Inc., ${ }^{111}$ stresses a balancing approach:

Where the statute regulates even-handedly to effectuate a legitimate local public interest, and its effects on interstate commerce are only incidental, it will be upheld unless the burden imposed on such commerce is clearly excessive in relation to the putative local benefits. . . . If a legitimate purpose is found, then the question becomes one of degree. And the extent of the burden that will be tolerated

103. $98 \mathrm{~S}$. Ct. at 2488.

104. Id. at 2488-89. See Hicklin, 565 P.2d at 164; ALASKA STAT. $\$ 38.40 .020$ (1977), quoted at note 4 supra.

105. See text accompanying notes 83-85 supra.

106. See text accompanying notes $86-89$ supra; authorities cited at notes 83,85 supra. Justice Brennan had proposed use of the two-step test in his dissent in Baldwin v. Fish \& Game Comm'n, 98 S. Ct. 1852,1870 (1978).

107. U.S. CoNST. art. I, \& 8, cl.3. On the relationship between the McCready ownership doctrine and the commerce clause, see note 57 supra. As for the privileges and immunities clause, it should be recognized that its protections overlap those of the commerce clause. See Hicklin, $98 \mathrm{~S}$. Ct. at 2491; TRIBE 411-12 n.19.

108. Heart of Atlanta Motel, Inc. v. United States, 379 U.S. 241, 256-60 (1964).

109. Breard v. City of Alexandria, 341 U.S. 622, 634-35 (1950).

110. Pike v. Bruce Church, Inc., 397 U.S. 137, 142 (1970).

111. 397 U.S. 137 (1970). 
will of course depend on the nature of the local interest involved, and on whether it could be promoted as well with a lesser impact on interstate activities. ${ }^{112}$

Under this formulation, the threshold inquiry is whether a challenged statute regulates or otherwise burdens interstate commerce. ${ }^{113}$ Residential preferences can violate the interstate commerce clause by restricting the interstate movement of natural resources or of labor. The natural resource issue arose in Pennsylvania $v$. West Virginia. ${ }^{114}$ In that case the Supreme Court held it an impermissible interference with commerce for West Virginia to require its gas producers to accord West Virginia consumers first right of purchase. The basis of the decision was that the local preference withdrew large quantities of the resource from interstate markets. ${ }^{115}$

The Court in Edwards.v. California ${ }^{116}$ confirmed that the movement of persons is "commerce" under the interstate commerce clause. ${ }^{117}$ At least one case, Brown v. Anderson, ${ }^{118}$ subsequently applied this holding to restrictions on the interstate flow of labor. The Brown court invalidated a domicile requirement for the use of certain Alaskan salmon fisheries on the grounds that the statute restricted the movement in commerce of nonresident fishermen. ${ }^{119}$

Once a burden on commerce is shown to exist, the question becomes whether the importance of local interests makes that burden constitutionally tolerable. ${ }^{120}$ An attempt by a state to advance its own economic interest is generally insufficient to override constitutional objections. ${ }^{121}$ Thus, in Pike, where the state's sole interest was the "tenuous" one of enhancing the reputation of its cantaloupes to increase their market demand, the Supreme Court found impermissible a re-

112. Id. at 142 .

113. See id. at 140-42. The Supreme Court, for example, has held that contaminated or unfit produce is not within the protection of the commerce clause. Id. at 143-44. Yet it recently found that solid and liquid waste does not constitute such a "quarantine" item. City of Philadelphia v. New Jersey, 98 S. Ct. 2531, 2538 (1978).

114. 262 U.S. 553 (1923).

115. Id. at 595 .

116. 314 U.S. 160 (1941).

117. Id. at 172. See authorities cited $i d$. at 172 n.l. Edwards struck down a statute making it a crime to assist in the immigration to Califomia of indigent nonresidents.

118. 202 F. Supp. 96 (D. Alas. 1962).

119. One could interpret this holding of Brown as dictum, however, since the court also deemed the statute violative of the privileges and immunities clause on the authority of Toomer. 202 F. Supp. at 102-03.

Perhaps because of its high unemployment and immigration rates and its vast supply of natural resources, Alaska has proven a prolific source of litigation over domicile and durational residency requirements. See Alleyne, supra note 38, at 7; Comment, supra note 71.

120. Pike v. Bruce Church, Inc., 397 U.S. 137, 142 (1970).

121. City of Philadelphia v. New Jersey, 98 S. Ct. 2531, 2535 (1978). 
quirement that Arizona-grown cantaloupes be packed in that state. ${ }^{122}$

The adverse effects of a state policy on interstate commerce can outweigh even a substantial local interest when the state could have promoted that interest in less burdensome ways. A recent example is Great Atlantic \& Pacific Tea Co. v. Cottrell, ${ }^{123}$ in which the state of Mississippi sought to permit the entry of out-of-state milk only when the sending state accepted Mississippi milk. The Supreme Court found that to serve its health interest Mississippi had the "obvious" and "less burdensome" alternative of applying her own standards of inspection to milk from nonreciprocating states. ${ }^{124}$

Turning to the possible interstate commerce effects of Alaska Hire, ${ }^{125}$ it is apparent that, unlike the consumer preference in Pennsylvania v. West Virginia, ${ }^{126}$ the Act's employment preference does not restrict the resource-oil and gas-in question. Indeed, the pipeline jobs covered by the law exist to aid in the oil's out-of-state delivery. ${ }^{127}$

The question whether the Alaska legislation, like that in Edwards and Brown, interferes with the movement of persons and labor in commerce deserves closer consideration. On the one hand it might be contended that Alaska Hire has only a small impact on the nation's labor pool. Its provisions do not apply to all private employment in the state or even to all private oil and gas employment. The Act reaches only oil and gas work on state-leased property or jobs directly related

122. 397 U.S. at 143, 145. But of. Hughes v. Alexandria Scrap Corp., 426 U.S. 794, 810 (1976) (Maryland, as purchaser, can prefer automobile hulks processed in-state since, if Congress is silent, the commerce clause does not apply when a state enters a market). The state of Alaska argued on the basis of Hughes that it could prefer its own workers when, through its lessees, it entered an employment market. Brief of Appellees, supra note 26, at 49 . One response is that the interstate movement of labor deserves more protection than that of business operations such as hulk processing. See text accompanying notes $139-42$ infra. See also the view of dissenting Justice Brennan in Hughes that the Pike test should apply regardless of whether the state enters a market as a purchaser. 426 U.S. at 827-29.

123. 424 U.S. 366 (1976).

124. Id. at 377 .

125. Although the Hicklin plaintiffs did not raise an interstate commerce clause challenge, the Supreme Court felt that an examination of interstate commerce cases such as Pennsylvania v. West Virginia, 262 U.S. 553 (1923), and Foster-Fountain Packing Co. v. Haydel, 278 U.S. I (1928), discussed at note 57 supra, would "inform analysis" under the privileges and immunities clause. 98 S. Ct. at 2491-92. The Court did not apply the Pike test, see quote accompanying note 112 supra, as does this Note. See text accompanying notes $125-42$ infra.

126. 262 U.S. 553 (1923). See text accompanying notes 114-15 supra.

127. See Hicklin, 98 S. Ct. at 2492 \& n.17.

Given the "profound national importance" of domestically produced oil in the United States, id. at 2492 \& n.18, any attempt to preserve Alaska's oil for Alaskans would undoubtedly place an undue burden on interstate commerce. Hicklin, 565 P.2d at 172 (Boochever, C.J., dissenting in part). 
thereto. ${ }^{128}$ The total coverage of local hire in 1976 amounted to six percent of the labor force of the country's least populous state. ${ }^{129}$ Further, one-quarter of the covered employment actually went to nonresidents, illustrating that the statute perfers, but does not require, Alaskan citizenship. ${ }^{130}$

It might be further argued that the domicile status that the Act prefers is available to anyone willing to establish it. However, establishing domicile is not burden-free. The migrant must forfeit the benefits of citizenship in his former state. ${ }^{131}$ Further, he must manifest his intent to make Alaska his permanent residence ${ }^{132}$-often an unrealistic requirement given the short-term, "boom-like" nature of many of the projects covered by Alaska Hire. ${ }^{133}$

The domicile preference may thus restrict the flow of labor to Alaska. To the extent the workers deterred by Alaska Hire represent the most qualified labor for the available positions, the preference interferes with the maximization of productivity in the nationally important Alaskan oil industry. This result might, in turn, discourage investment in the industry. In short, as a result of the obstacles it poses to the free movement of labor, Alaska Hire "does affect and burden interstate commerce." 134

The issue thus devolves into whether local interests outweigh this burden. ${ }^{135}$ Alaska's justification for local hire-securing employment for its people-looms as a substantial one under the commerce clause. ${ }^{136}$ Yet under the Pike test ${ }^{137}$ a countervailing factor exists in Alaska's ability to promote this goal by the alternative means of providing manpower programs and limiting its hiring preference to unemployed Alaskans. These alternatives appear to place less of a burden on commerce in that out-of-state workers would not have to become Alaskan domiciles to qualify for the same hiring priority as employed

128. AlaSka STAT. \& 38.40.050(a) (1977), quoted at note 1 supra; Brief of Appellees at 6-7, Hicklin v. Orbeck, 565 P.2d 159 (Alas. 1977).

129. See Hicklin, 565 P.2d at 161 n.1. The percentage would undoubtedly have increased with the upcoming construction of the Alaska natural gas pipeline.

130. Id at 166; Brief of Appellees, supra note 128, at 12-13. The 25\% figure, however, may reflect the fact that the state did not seriously enforce Alaska Hire until 1975. See Reply Brief of Appellants at 10-11, Hicklin v. Orbeck, 565 P.2d 159 (Alas. 1977).

131. See note 25 supra.

132. Alaska STAT. $\$ 38.40 .090(1)(\mathrm{E})$ (1977), quoted at note 6 supra.

133. See Hicklin, 565 P.2d at 164 .

134. Pike v. Bruce Church, Inc., 397 U.S. 137, 142 (1970).

135. Id.

136. Id at $145-46$ (citing Toomer v. Witsell, 334 U.S. $385,403-04$ (1948)).

137. See quotation in text accompanying note 112 supra. 
Alaskans. ${ }^{138}$

Whether the burdens on commerce outweigh the local interests involved in Alaska Hire is, to be sure, not subject to precise determination. However, the commerce clause holding of Toomer proves helpful by analogy. A provision of the statute in question ${ }^{139}$ required that owners of shrimping boats fishing off the South Carolina coast pack their catch in that state. The Supreme Court held that despite South Carolina's substantial interest in promoting local employment, the likelihood that packing operations could be performed more efficiently elsewhere placed an undue burden on commerce. ${ }^{140}$ An appealing argument thus can be made ${ }^{141}$ that, despite Alaska's interest in reducing unemployment, the free movement of labor, if jeopardized by Alaska Hire, deserves just as much commerce clause protection as the movement of business operations in Toomer or, for that matter, the flow of inanimate resources in Pennsylvania v. West Virginia. ${ }^{142}$

\section{Dimensions of State Leasing Power}

The Supreme Court in 1940 suggested that, "[l]ike private individuals and businesses, the Government enjoys the unrestricted power . . . to determine those with whom it will deal, and to fix the terms and conditions upon which it will make needed purchases." 143 This analogy of the government to a private contractor draws its early support from the companion cases of Heim v. McCall ${ }^{144}$ and Crane v. New York. ${ }^{145}$ In both of these cases, aliens and nonresidents attacked a New York law that required private companies and government agencies with public works contracts to hire state citizens preferentially. The Supreme Court, in sustaining the statute in Heim, relied on what has become known as the "special public interest doctrine": 146 " $[\mathrm{I}] \mathrm{t}$

138. See text accompanying notes $94-97$ supra.

139. 1936 S.C. Acts 1412 (struck down as unconstitutional, Toomer v. Witsell, 344 U.S. 385 (1948)).

140. 344 U.S. at 403-04.

141. Brief of Appellants, supra note 24, at $31 \mathrm{n} .21$.

142. 262 U.S. 553 (1923). Cf. Edwards v. California, 314 U.S. 160, 177 (1941) (Douglas, J., concurring) (right of interstate travel occupies a more protected position than does interstate movement of cattle or inanimate resources).

143. Perkins v. Lukens Steel Co., 310 U.S. 113, 127 (1940). The case involved a challenge to the Secretary of Labor's determination of the minimum wages would-be government contractors were to provide their employees. The Court dismissed the complaint for lack of standing, but Congress subsequently overturned the decision. See W. GellhorN \& C. Byse, AdministraTIVE LAW; CASES AND COMMENTS 178-79 (6th ed. 1974).

144. 239 U.S. 175 (1915).

145. 239 U.S. 195 (1915).

146. Sugarman v. Dougall, 413 U.S. 634, 644 n.11 (1973). 
belongs to the State, as guardian and trustee for its people, and having control of its affairs, to prescribe the conditions upon which it will permit public work to be done on its behalf . . . ."147 In the state court ruling in Crane, Judge Cardozo had made the similar statement that "[t]he state, in determining what use shall be made of its own moneys, may legitimately consult the welfare of its own citizens . . . ."148

These statements indicate that the basis of the special public interest doctrine rests on the fact that the government uses money over which it has a proprietary interest. ${ }^{149}$ The argument continues that the government, like a private contracting party, should enjoy complete freedom in spending its own funds.

In applying this line of reasoning to justify Alaska Hire, the state of Alaska substituted state oil leases for the government construction contracts in Heim and Crane. ${ }^{150}$ It then maintained that it could affix such conditions as it pleased-including first-hired, last-fired preferences for Alaskans-to these leases. ${ }^{151}$ Since the oil companies were free to reject the leases and seek oil elsewhere, Alaska Hire might be seen as merely a valid, noncoercive exercise of the state's capacity to act as a private lessor, free from constitutional restraints. ${ }^{152}$

147. 239 U.S. at 191 (quoting Atkins v. Kansas, 191 U.S. 207, 222-23 (1903) (contract to build a municipal highway)).

148. People v. Crane, 214 N.Y. 154, 164, 108 N.E. 427, 430, affd sub nom. Crane v. New York, 239 U.S. 195 (1915).

149. See Hicklin, 565 P.2d at 172 n.4 (Boochever, C.J., dissenting in part); People v. Crane, 214 N.Y. 154, 162, 108 N.E. 427, 429, aff'd sub nom. Crane v. New York, 239 U.S. 195 (1915).

150. See Brief of Appellees, supra note 26, at 47-48; Alleyne, supra note 38, at 9.

151. Brief of Appellees, supra note 26 , at $46-49$.

152. Brief of Appellees, supra note 128, at 54, 57. In addition to the specific objection made infra, see text accompanying notes 153-60 infra, several general limitations govern the use of this analogy. First, in contracting or leasing, a state government must promote a constitutionally permissible objective. See Note, Unconstitutional Conditions, 73 HARv. L. Rev. 1595, 1603 (1960). Alaska, of course, seeks to reduce unemployment and spur oil production-both legitimate state activities.

Second, when the government grants a privilege, such as a lease, which requires the grantee to relinquish a constitutional right, the doctrine of unconstitutional conditions may apply to invalidate that condition. See Hale, Unconstitutional Conditions and Constitutional Rights, 35 CoLUM. L. REv. 321 (1935). The Hicklin plaintiffs did not raise an unconstitutional conditions argument. For one thing, the grantees of the lease privilege in Hicklin were the employers, not the employeeplaintiffs. But even assuming that the doctrine extended to third parties-a notion contradicted by Professor Hale, id. 327-28 (citing Blake v. McClung, 172 U.S. 239, 254-55 (1898))-the objection remains that the employees are not in the position of accepting work upon the relinquishment of a constitutional right. Rather, the asserted unconstitutionality is that the government has discriminated against nonresidents by depriving them of work altogether. With one exception, nothing the plaintiffs could "relinquish" would qualify them for employment under the oil leases. That exception is their out-of-state domicile. Yet no constitutional right to non-Alaskan domicile exists, nor does a bona fide residency requirement require the relinquishment of the plaintiffs' related constitutional right to interstate migration. See note 101 supra. Compare the applicability of the doctrine of unconstitutional conditions to the situation in which the state conditions 
Yet, paralleling the fate of the $M c C r e a d y$ resource-ownership exception to the privileges and immunities clause, ${ }^{153}$ the "special public interest doctrine" of Heim and Crane has not withstood the test of time. The Supreme Court all but "dealt a death blow"154 to the doctrine by finding state proprietary interests insufficient to support the denial to aliens of the right to engage in commercial fishing, ${ }^{155}$ to receive welfare assistance, ${ }^{156}$ and to secure public employment. ${ }^{157}$ The Court then summarily affirmed a district court invalidation of the successor to the New York public works law involved in Heim and Crane as it applied to employers wishing to hire aliens. ${ }^{158}$ In all these cases the Court strictly scrutinized the challenged statutes because of alleged discrimination against aliens. In Hicklin the Supreme Court speculated that some vitality might remain in the Heim-Crane doctrine due to the fact that it had not yet come under attack from nonresident citizens. ${ }^{159}$ However, the Court flatly rejected applying any of the doctrine's remaining vitality to protect the "pervasive discrimination" mandated by Alaska Hire. ${ }^{160}$

Without the immunity that a still viable Heim-Crane doctrine might provide the government as lessor, the significance of the lease in Alaska Hire is only that it represents one of the varied manifestations

public employment on the surrender of first amendment rights. See Keyishian v. Board of Regents, 385 U.S. 589 (1967). For other examples, see Note, Democratic Due Process: Administrative Procedure After Bishop v. Wood, 1977 DukE L.J. 453, 471 n.102.

153. See text accompanying notes 33-48 supra.

154. Purdy \& Fitzpatrick v. State, 71 Cal. 2d 566, 584, 79 Cal. Rptr. 77, 89, 456 P.2d 645, 657 (1969).

155. Takahashi v. Fish \& Game Comm'n, 334 U.S. 410 (1948).

156. Graham v. Richardson, 403 U.S. 365 (1971).

157. Sugarman v. Dougall, 413 U.S. 634 (1973).

158. C.D.R. Enterprises, Ltd. v. Board of Educ., 412 F. Supp. 1164 (E.D.N.Y. 1976), affd sub nom. Lefkowitz v. C.D.R. Enterprises, Ltd., 429 U.S. 1031 (1977). Accord, Purdy \& Fitzpatrick v. State, 71 Cal. 2d 566, 584, 79 Cal. Rptr. 77, 89, 456 P.2d 645, 657 (1969).

159. 98 S. Ct. at 2491 n.15. Cf. Salla v. County of Monroe, 90 Misc. $2 d$ 427, 395 N.Y.S.2d 366 (Sup. Ct. 1977) (nonresident American citizens successfully challenged under strict scrutiny 12month durational residency requirement included in successor to New York public works law involved in Heim and Crane).

160. $98 \mathrm{~S}$. Ct. at $2491 \&$ n.15. Even assuming the continued validity of Heim and Crane as applied to nonresident American citizens, a possible basis for distinguishing these cases exists. Heim and Crane involved the construction of subways and sewers, both of which are projects that may be considered "public work." Heim, 239 U.S. at 19I, quoted at text accompanying note 147 supra. Alaska Hire, however, does not involve what one would ordinarily consider "public work." Except for the leasing connection, all states have left the construction and operation of their oil distribution systems to the private sector. Further, the Heim-Crane doctrine rested largely on the use of the government's own monies. See text accompanying notes 148-49 supra. In contrast, the Alaska pipeline, to which Alaska Hire applies, see note 1 supra, involves history's greatest single-project outlay of funds by private enterprise. 
of state action. ${ }^{161}$ A state should no more be allowed to impair constitutional rights through a lease than through direct regulation. The mere fact that it was through its leasing power that Alaska infringed the privileges and immunities and interstate commerce clauses does not save the Alaska Hire Act from its constitutional infirmities.

\section{CONCLUSION}

The nondurational residence preference of Alaska Hire had two constitutional failings. First, it violated the privileges and immunities clause. That clause applies because the McCready exception, based upon the anachronism of considering common ownership of resources a basis for preferential treatment of state residents, has lost its validity. Alaska Hire offended the clause by unnecessarily distinguishing between nonresidents and employed residents in an attempt to reduce local unemployment. Second, the Act created an undue burden on interstate commerce, thus running afoul of the commerce clause. Its domicile requirement, especially when weighed against the express goal of reducing unemployment, placed too significant an impediment on the free flow of labor. The fact that the state's function in the local hiring plan was that of lessor could not have insulated the program from these constitutional defects.

Alaska Hire also threatened to open up a Pandora's box of state restrictions on the employment of nonresidents. ${ }^{162}$ Although some such restrictions may be unobjectionable, such as bona fide residence requirements for state or municipal employment, ${ }^{163}$ serious objections arise when a domicile preference expands into the private sector. The Chief Justice of the Alaska Supreme Court, for example, raised the spectre of an extension of local hiring to leases of state dairy, agricultural, mining and lumber lands. ${ }^{164}$ Assuming the goal of such a sizeable extension to be the reduction of local unemployment, the Toomer privileges and immunities clause test would raise strong objections to the unnecessary relegation of nonresidents to last in hiring priority.

161. See Turner v. City of Memphis, 369 U.S. 350 (1962); Burton v. Wilmington Parking Auth., 365 U.S. 715 (1961).

162. Hicklin, 565 P.2d at 173 (Boochever, C.J., dissenting in part).

163. See cases cited at note 64 supra. Unlike the domicile preference of Alaska Hire, most of these requirements have undergone review only for minimum rationality under the equal protection clause. See note 71 and accompanying text supra. Further, the governments involved have managed to offer objectives, such as employee loyalty and recovery of training costs, that make bona fide residency a criterion more tailored to their achievement than is residency with respect to reducing unemployment. For a compendium of cases see Alleyne, supra note 38, at 10 n.46.

164. Hicklin, 565 P.2d at 173 (Boochever, C.J., dissenting in part). 
Moreover, the inhibition of movement of qualified out-of-state labor into these key industries might significantly affect interstate commerce.

The most extreme use of local hiring by a state would consist of its implementation in all private enterprise through direct regulation. Of course, with the demise of the McCready and Heim-Crane doctrines, the absence in such a program of any link to natural resources or to a governmental lease actually has little bearing on its constitutionality. Rather, the barriers to such pervasive regulation lie in more pronounced versions of the same constitutional objections that would arise when the hiring preference is confined to government-leased industries. ${ }^{165}$

The most intimidating scenario is the possibility of all states enacting employment preferences. ${ }^{166}$ One might presume that more nonresidents who travel to Alaska for work are disposed to become domiciled in their workplace than are New Jersey and Connecticut commuters who work in New York City. ${ }^{167}$ Thus, a "New York resident hire law" unrelated to the special local interests governing public employment ${ }^{168}$ might impose considerable burdens on the interstate flow of labor. ${ }^{169}$ Moreover, as states created obstacles to immigration in efforts to reduce unemployment among their own residents, the effect might be merely to create unemployment problems in nearby states. The end result might be a retaliatory use of local hiring preferences, producing a "Balkanization of interstate commercial activity" 170 in which "each state would become a separate and isolated enclave."171

Although Alaska Hire had not produced these drastic consequences as of 1978, a compelling policy basis existed for the Supreme

165. See note 63 supra and accompanying text.

166. See Hicklin, 565 P.2d at 173-74 (Boochever, C.J., dissenting in part). Prior to Hicklin at least 18 states had resident hire laws applicable to private contractors on public construction or procurement activities. Brief of Appellees, supra note 26, at 8 n.4. Certainly, the fact that the funds involved are in a sense "owned" by the government would no more save these laws than did the parallel Heim-Crane notion in Hicklin that as a lessor the state can act freely. See text accompanying notes 150-60 supra. Also, unlike the case of public employment, see note 163 supra, it would seem difficult for a state to assert that the close nexus between domicile and employee loyalty is relevant to public works employees. Finally, as a means of reducing unemployment, public works laws that require the hiring of residents would be subject to the same means-ends objections as Alaska Hire. But see People ex rel. Holland v. Bleigh Constr. Co., 61 Ill. 2d 258, 273, 335 N.E.2d 469, $478-79$ (1975) (preference for Illinois laborers on public works projects bears a "close relation" to goal of providing employment for residents). Thus, Hicklin would appear to have made these laws constitutionally suspect.

167. But see text accompanying notes 132-33 supra.

168. See note 163 supra.

169. For a discussion of the equal protection clause fate of New York's preference for "citizens" in public works hiring, see text accompanying notes 144-46, 153-58 supra.

170. Douglas v. Seacoast Prods., Inc., 431 U.S. 265, 286 (1977).

171. Hicklin, 565 P.2d at 174 (Boochever, C.J., dissenting in part). 
Court's invalidation of the Act in order to avert such a result. But even on its own constitutional merits, Alaska's local hiring scheme was faulty. The United States Constitution does not permit a state to solve its unemployment problems by imposing employment discrimination on nonresidents. 